\title{
EDITORIAL
}

\section{The impact of student-faculty partnerships on student partners who become academics}

\author{
*Amrita Kaur, School of Psychology, WenzhouKean University, China. \\ Anthony Cliffe, Academic Skills, University of Chester, United Kingdom.

\begin{abstract}
Abderrahim Benlahcene, School of Education and Modern Languages, University Utara Malaysia, Malaysia.
\end{abstract}

Mohammad Noman, Graduate School, WenzhouKean University, China.

Contact: akaur@kean.edu

A few months ago, Amrita Kaur, first author of this editorial, IJSaP editorial board member, and a faculty member working in China, had an informal discussion on the impact of Students as Partners (SaP) with Anthony Cliffe, a former student partner and former member of the UK editorial team of IJSaP. The inspiration for this editorial was Anthony's remark during the conversation: "I believe that if student partners choose to join academia, they will make excellent, compassionate, open, and understanding academics with plenty of respect, trust, and belongingness for their students." His assertion struck a chord with Amrita, since she had always been curious about the impact these collaborative experiences have on students in forming their professional identities, thoughts, interactions, and engagements while enacting partnership values. That conversation initiated a dialogue between two faculty members (Mohammad Noman in addition to Amrita Kaur) and two former student partners who had recently joined the academic workforce (Rahim Benlahcene in addition to Anthony Cliffe).

In the spirit of sustaining the dialogue that inspired this editorial and the values that IJSaP aims to foster, this editorial offers individual reflections of two former student partners who are currently academics. They share their journeys as student partners, the impact of their partnership experiences on their current professional identities, and how these have helped them enact partnership values in their professional roles. The two faculty authors collectively interpret the former student partners' reflections and add their own perspectives as those who worked from the other side of partnership as academics first, sharing how they created space for their student partners to grow as academics to carry forward Student-as-Partner (SaP) values.

Drawing from those dialogues and the literature on student partners' reflections of life lessons (e.g., Encabo, 2013; O'Hara, 2013; Kaur et al., 2021), we propose that partnership experiences equip student partners with the necessary competencies and mindsets to enact partnership values as professionals. Specifically, partnership prepares student partners who 
become academics to enact the values of trust, reciprocity, respect, responsibility, authenticity, inclusivity, empowerment, challenge, and community (Higher Education Academy, 2015). CookSather (2011) draws upon student consultants' reflections and describes how student-faculty partnership learning gains, which are multilayered, can extend beyond classroom learning and become valuable life lessons as student partners develop "critical perspective within and beyond classrooms and build greater confidence, capacity, and agency as learners and as people" (p. 41).

\section{FROM STUDENT PARTNERS TO FACULTY MEMBERS}

Anthony: As my comment, which Amrita quoted at the start of this editorial outlined, as a student partner who has become an academic, I feel very passionate about those who enact SaP going on to "walk the talk" in academia. Prior to engaging in SaP work as a student, I was completely unaware of it. I then ended up through serendipity being an IJSaP co-editor while studying for my Ph.D. This was an entirely brand-new field for me. Spending 4 years with the journal, having conversations with the editorial board, reading the many fantastic papers, and interacting with experts in the field gave me a holistic view of SaP and a deep appreciation for $\mathrm{SaP}$ values. This has helped in my former role as a senior lecturer of geography at the University of Chester, UK, and now my current role as an academic study skills advisor in the same institution.

Rahim: I was remotely aware of the term "Students as Partners" through some work my Ph.D. supervisor had done. Later, my Ph.D. supervisor introduced me to SaP and invited me to join the Malaysian team of the IJSaP editorial board. My participation in the board gave me the opportunity to engage with scholars in the field and to witness the enactment of partnership principles within the board. I also had the opportunity to partner in other projects while being a student. Currently, I am a lecturer at Universiti Utara Malaysia, Malaysia, and teach undergraduate courses in psychology.

\section{THE EXPERIENCES OF SAP VALUES AND FORMATION OF PROFESSIONAL IDENTITIES}

Anthony: SaP, for me, is about having your voice heard and acknowledged as a student. However, the breakdown of the traditional power dynamics is most welcome; it is one of the values that SaP promotes; it has changed me as a person and now as an academic. The key values that come to mind when I reflect on my journey are trust, honesty, adaptation, and compassion.

First, trust, I feel, is essential in any relationship, but especially in SaP because both academics and students are giving up something of themselves for the project to work. By that I mean the academic is relinquishing power and trusting the student. In reverse, a student is being entrusted with the project's direction and trusts that their voice is not only heard but also listened to. To be honest and frank with your students is something that I believe students appreciate. Having become an academic, I find being entirely open with students about the challenges and constraints that we as academics face in our daily lives is refreshing to students. It is important for them, for instance, to understand budget constraints, shortage of time, and university politics. I believe SaP academics like to reduce the "us vs. them" attitude which persists in academia. Had I not been a part of SaP as a student, I don't think I'd have that view. 
This is where adaptability comes into my reflections on my SaP journey. Having gone from no knowledge at all to being a part of an editorial board surrounded by experts was at first intimidating, and I felt the ever-present imposter syndrome. However, what became apparent very early on is that, because I had no prior knowledge, I could see things differently and came to things from a different angle. My perspectives had been formed by my previous experiences, my academic discipline, and my personality. I had value. This is where I experienced the epiphany of students as keepers of expert knowledge (i.e., experts in being students and what they need and want as students), but students need a welcoming and supportive space for that to grow.

Finally, SaP promotes compassionate academics. SaP to me starts at the grassroots. It begins with academics being open to relinquishing power, being honest about themselves, and learning when mistakes happen. It's about having open and frank and, at times, uncomfortable conversations with students, especially around pre-conceived biases, misuse of gender pronouns, and colonization of the curriculum. It's about having the compassion to understand that students face many complex issues in their lives, no more so than in the past year with COVID, and understanding that students bring so much to the table regarding views and knowledge. It is the role of a SaP academic to allow space to nurture that seed. If academics allow this, students involved in SaP get to experience all of that emotion. It changes you fundamentally as a person inside and outside of academia to become someone open to change, flexible enough to see the world through someone else's lens, and brave enough to relinquish power.

Rahim: My experience as a student partner in various partnership projects has provided me with extraordinary experiences which underline how important human relationships and compassion are to learning. Those experiences have also shaped various aspects of my personality as an individual. I have learned the value of respect that one can demonstrate by listening to a variety of perspectives. The most important thing that I learned from my partnership practice is that lecturers can learn a lot from their students and benefit from their perspectives, especially if students are from different generations. As an academic, I now view my students as essential partners in analyzing the learning in my courses.

I feel fortunate to have been given space for my voice to be heard and acknowledged. That's the value of humility that my faculty partners demonstrated by trusting in my abilities. That experience has removed several inhibitions that I might have had as a student and has instilled optimism in my personality. Those partnership experiences also opened a new way for me to view academia. I keep reminding myself to remain open to those changes. Furthermore, the partnerships brought me closer to my faculty partner's work systems. I am better able to understand where they are coming from and how they juggle several roles in their professional lives with integrity.

\section{CARRYING FORWARD PARTNERSHIP VALUES AS ACADEMICS}

Anthony: As an academic, I am deeply aware that my students possess some wonderful insights and experiences, and that I regularly hold my hand up and admit when I'm not an expert at something. I recognize that students are adults; an academic should never be dismissive of students' suggestions or comments. As an academic, I have found that having experienced SaP has allowed me to feel comfortable with being uncomfortable, especially 
around that inward reflection of my practice. I'm open to change; I'm open to learning and understanding. In my first year as an academic, I was nominated by students in the department for the university award for the most inspiring lecturer of 2019. I was deeply humbled to read the anonymous feedback submitted to the students' union by my students. In their nomination of me, they talked about being treated as equals, that I was open to discussion and change, and how that had helped them grow as individuals.

Rahim: There are many ways in which my experiences as a student partner have not only supported me as a student to excel but also provided me with a new perspective on how to perform my job. For example, now when I supervise my students, I pay conscious attention to my communication style. I understand the profound impact my words and style of conversation can have on students' emotions and motivations to continue to study. I act as a facilitator, not as a dominant lecturer with my students. This approach comes naturally to me since I am sure that I can trust my students. I am less anxious about any conflicts that may occur and more open to trying new ways of teaching.

Being a student partner, I have learned that the lecturer should respect student diversity in terms of their background knowledge, especially language proficiency, for learning to occur. Now, I carefully think about my teaching approaches and often adopt alternative methods to consider individual differences among my students. Having had the privilege of being heard and respected as a student, I would like to ensure that I create the same opportunities for my students.

\section{EXPERIENCING AND SUPPORTING SAP AS ACADEMICS FIRST}

While Anthony and Rahim developed a sense of the potential of pedagogical partnership first as student partners and then as academics, Amrita and Noman developed these sensibilities and commitments first as academics. Research is emerging on the faculty attitudes and intentions that contribute to realizing the transformative potential of studentfaculty partnership (Cook-Sather \& Kaur, in press, and it is different to develop these as academics, rather than to have first experienced them as student partners. In this section, Amrita and Noman reflect on what they had to learn as academics, that Anthony and Rahim learned first as student partners, and on what they do as academics to support the development of student partners.

\section{EXPERIENCING SAP AS ACADEMICS FIRST}

In 2017, while working on a scholarship of teaching and learning project, Amrita came across Cook-Sather's (2017 video on student-faculty partnership and decided to pursue this concept in the Malaysian context. She noticed that, despite cultural challenges, this concept has enormous pedagogical potential both for students' and faculty's academic and personal gains. Noman, who initially was skeptical of the concept but encouraged by Amrita, began with a few small-scale collaborations and came to realize the transformative potential this approach can constitute for student and faculty development.

Since then, we have both come to realize that the change in the relationship dynamic between faculty and students as a result of dialogue, reciprocity, and respect nurtured during the collaborations contributes in powerful ways to teaching and learning. We began to see our students in a different light as they became more proactive, articulate, and responsible in 
working towards shared goals. The process is organically engaging and intrinsically motivating for both parties (Kaur \& Noman, 2019). Additionally, for us, these collaborations prompted moments of self-reflection that led to revisions and improvements in our practices as faculty, which in turn expanded our belief in the transformative potential of this practice (Cook-Sather \& Kaur,in press). Our mindsets for student collaborations have expanded. Now, we consciously seek opportunities to involve students in whatever ways we can in our academic endeavors. We have developed the conviction that we can guide students to choose their paths and later pave the path together.

\section{SUPPORTING SAP AS ACADEMICS FIRST}

Initiating and sustaining partnership collaborations requires open-mindedness, courage, and persistence from both sides. We, despite being excited about this new approach, were completely unprepared, uncertain, and anxious about accepting new roles. Nevertheless, our experiences of successful collaborations imbued us with conviction in this practice. We understood that for students to navigate their roles successfully and gain maximum benefit from these collaborations for their future professional identities, we needed to inspire competency beliefs and support students in developing the ability to articulate their thoughts openly, which includes being honest about themselves and making independent decisions. Therefore, each step in our collaboration needed to be carefully crafted so that the students had the opportunity to acquire those skills. Creating opportunities to work outside of formal, structured classroom settings was our central aim.

As students assumed new roles by becoming proactive and accountable, we as faculty had to consciously create spaces for students to perform their part. We learned to step back, taking time to listen patiently to what students had to say. We made a conscious effort to make collective decisions through intense yet productive dialogues during those partnerships. These contributed to a partnership ethos; as a student in one of our collaborations suggested, "Those moments proved to be affirmative and promoted active participation." It also inspired students to feel they "had the confidence of an expert" and "could make a greater impact" (Kaur et al., 2021, p.8).

By acknowledging the fact that students' lived experiences and how they deal with them can have a profound impact on their identities as professionals, we ensured that the language of our interaction with students was open, welcoming, and affirmative. In our collaborative research supervision project, a student mentioned that "working along with my supervisor has benefitted me to expand my language for supervision. I have become careful in the choice of my words for feedback as I know they can affect their performance and motivation immensely" (Kaur et al., 2021, p. 9). We frequently acknowledge their contribution in making the collaboration successful and in helping achieve the collective goal, which in turn builds competency beliefs.

\section{SAP AND PROFESSIONAL LEARNING: REFLECTIONS AND EVIDENCE FROM THE LITERATURE}

The reflections of two student partners who became academics demonstrate the potential of SaP experiences to create well-rounded individuals with value-based professional identities that academics can enact in their workplace. The literature on students' gains through partnerships demonstrates that student partners re-conceptualize themselves, as 
Cook-Sather and Luz (2015) note: "it is not only how they think and behave that changes but also who they are" (p. 1102; see also Cook-Sather, 2014). A consultant in the Students as Learners and Teachers (SaLT) program at Bryn Mawr and Haverford Colleges, USA reports that "the language that I developed through being a consultant, and the skills/strategies I learned about problem-solving, will stick with me long after the consulting experience is over" (CookSather \& Luz (2015, p. 1103).

Former student partners have written about how they carry partnership values into their teaching practice in pre-college settings. For example, Encabo (2015) writes that participating in partnership work at Bryn Mawr College as an undergraduate taught her to think like a teacher, pay attention to nuances, and keep an eye on her personal bias, which can impact teaching practices. Another student partner, O'Hara (2015), writes about the mindset she gained upon participating in the same partnership program: "I keep in mind how powerful the simplest things can be in a classroom, and always try to give my students voice and choice" (p. 3). These comments suggest that the profound experiences of student partners can be translated into and manifested in their professional practices in the future.

The student partners who are now academics express their readiness to relinquish power to overcome the traditional divide between faculty and students and move towards establishing egalitarian learning communities (Matthews et al., 2018). They demonstrate openmindedness and are prepared to embrace change. Because they were heard in their collaborations with their faculty partners, they have developed the capacity to listen to their students. This transformation is indicative of the profound effect partnerships had on their hearts and minds. Student partners had first-hand experience working together with their faculty and co-constructing knowledge. This helped build a narrative that both participants are equally important in the learning and construction of knowledge, which facilitated affiliation between students and faculty. These student partners who have become academics have reconceptualized the meaning of power in the relationship of teacher and student.

In reflecting on their journey from student partners to academics, Anthony and Rahim highlight the value of compassion and propose it as a cornerstone of their professional identity as faculty. Being compassionate facilitates imagining, for example, what it is like to be a student. This kind of imagining in turn allows faculty to be open-minded, to listen to and acknowledge students' perspectives, respect diversity, and be inclusive.

As faculty, Amrita and Noman proactively recognized the skills and competencies to be nurtured among student partners for their professional identities. In their reflection, they make it explicit that while they created spaces for student partners' roles to be enacted and voices to be heard, they also transformed their professional identities for enacting SaP values. They put their trust in the act of modelling" and the lived experiences of student partners to nurture SaP values. For example, in their study where student partners collaborated for peer supervision (Kaur et al., 2021), they shared learning compassion and respect for students through the practices of their supervisors. One student explained: "While you are listening or reading someone's research, sometimes meaningless ideas tend to irritate you. But, by observing our supervisor talk to junior students, I learned how to articulate my perspective regarding master's students' work without being mean" (p. 9). In discussing the professional learning of doctoral supervisors, Wisker and Kiley (2014) observe that "for some, the only exposure to models of supervision is the practice of their own supervisor(s)" (p. 125). This point suggests a strong 
likelihood that students' professional identity is informed to some degree by their experiences of interaction and relationship with their faculty while at university. Student-faculty collaboration offers a great opportunity for faculty to enact partnership values and have student partners experience them for their professional learning. Future studies may explore the impact of such partnerships on students' professional identities in professions outside of academia.

\section{CONCLUSION}

Student partners' experiences of participating in partnership provide them with an opportunity to reflect consciously on the values and ethics they may want to embrace as professionals. Since as students partners they were at the receiving end of their faculty partners' values and actions, they are better able to appreciate the power of partnership values and may want to uphold them when they are at the other end.

We hope the accounts above inspire academics to embrace SaP projects. Know that a student whom you work with may, one day, become an academic and take the partnership experience with them to continue that change that you are enacting right now. Recognize that SaP for students can make them individuals who value equality, respect voices, and believe in the construction of knowledge regardless of what industry they end up in.

\section{ACKNOWLEDGEMENTS}

We would like to thank Alison Cook-Sather, Mick Healey, and Kelly E. Matthews for contributing meaningful insights to improve this work.

\section{NOTE ON CONTRIBUTORS}

Amrita Kaur is assistant professor of psychology at Wenzhou-Kean University in China. Her research interests include teaching, learning, and assessment in higher education; students as partners; learning motivation and engagement; and cross-cultural studies for learning.

Anthony Cliffe is a former senior lecturer in geography and is now an academic skills advisor at the University of Chester. His research interests are contemporary digital technologies for teaching and learning.

Abderrahim Benlahcene is a lecturer at the school of education, University Utara Malaysia. He teaches psychology courses to undergraduate and postgraduate students. His research interest includes motivation, engagement, and goal orientations.

Mohammad Noman is assistant professor of education leadership and the coordinator of the EdD program at Wenzhou-Kean University in China. His research interests include educational leadership and adult pedagogy. 


\section{REFERENCES}

Cook-Sather, A. (2011). Layered learning: Student consultants deepening classroom and life lessons. Educational Action Research, 19(1), 41-57.

https://doi.org/10.1080/09650792.2011.547680

Cook-Sather, A. (2014). Student-faculty partnership in explorations of pedagogical practice: A threshold concept in academic development. International Journal for Academic Development, 19(3), 186-198. https://doi.org/10.1080/1360144X.2013.805694

Cook-Sather, A. (2017, March 6). Alison Cook-Sather on partnerships between students and faculty [Video]. YouTube. https://www.youtube.com/watch?v=Spwl-con6V0\&t=6s

Cook-Sather, A., \& Kaur, A. (in press). Naming and nurturing faculty attitudes and intentions critical to realizing the transformative potential of student-faculty pedagogical partnerships. Journal of Educational Innovation, Partnership and Change.

Cook-Sather, A., \& Luz, A. (2015). Greater engagement in and responsibility for learning: What happens when students cross the threshold of student-faculty partnership. Higher Education Research \& Development, 34(6), 1097-1109.

https://doi.org/10.1080/07294360.2014.911263

Encabo, M. (2015). Developing “middle" pedagogy. Teaching and Learning Together in Higher Education, 1(14), 2. http://repository.brynmawr.edu/tlthe/vol1/iss14/2.

Higher Education Academy. (2015). Framework for student engagement through partnership. HE Academy. https://www.heacademy.ac.uk/sites/default/files/downloads/studentenagagement-through-partnership-new.pdf

Kaur, A., Kumar, V., \& Noman, M. (2021). Partnering with doctoral students in research supervision: Opportunities and challenges. Higher Education Research \& Development. https://doi.org/10.1080/07294360.2020.1871326

Kaur, A., \& Noman, M. (2020). Investigating students' experiences of Students as Partners (SaP) for basic need fulfilment: A self-determination theory perspective. Journal of University Teaching \& Learning Practice, 17(1). https://ro.uow.edu.au/jutlp/vol17/iss1/8

Matthews, K. E., Cook-Sather, A., \& Healey, M. (2018). Connecting learning, teaching, and research through student-staff partnerships: Toward universities as egalitarian learning communities. In V. C. H. Tong, A. Standen, \& M. Sotiriou (Eds.), Research equals teaching: Inspiring research-based education through student-staff partnerships (pp. 2329). University College of London Press

O'Hara, M. (2015). Multiple iterations of partnership: My co-creation journey as a student and a teacher. Teaching and Learning Together in Higher Education, 14, 4. http://repository.brynmawr.edu/tlthe/vol1/iss14/4 
Wisker, G., \& Kiley, M. (2014). Professional learning: Lessons for supervision from doctoral examining. International Journal for Academic Development, 19(2), 125-138.

https://doi.org/10.1080/1360144X.2012.727762 